\begin{tabular}{|l|l|l||}
\hline \multicolumn{2}{|c|}{ PublisherInfo } \\
\hline \hline PublisherName & $:$ & BioMed Central \\
\hline \hline PublisherLocation & $:$ & London \\
\hline \hline PublisherImprintName & $:$ & BioMed Central \\
\hline \hline
\end{tabular}

\title{
Anti-annexin V antibodies in patients with scleroderma
}

\begin{tabular}{|l|l|l||}
\hline \multicolumn{2}{|c|}{ ArticleInfo } \\
\hline \hline ArticleID & $:$ & 33 \\
\hline \hline ArticleDOI & $:$ & $10.1186 /$ ar-1999-66758 \\
\hline \hline ArticleCitationID & $:$ & 66758 \\
\hline \hline ArticleSequenceNumber & $:$ & 29 \\
\hline \hline ArticleCategory & $:$ & Paper Report \\
\hline \hline ArticleFirstPage & $:$ & 1 \\
\hline \hline ArticleLastPage & $:$ & 3 \\
\hline \hline & & RegistrationDate : 1999-12-1 \\
\hline ArticleHistory & $:$ & OnlineDate \\
\hline \hline ArticleCopyright & $:$ & Current Science Ltd1999-12-1 \\
\hline \hline ArticleGrants & $:$ & \\
\hline \hline ArticleContext & $:$ & 130752211 \\
\hline \hline
\end{tabular}




\section{Keywords}

Annexin V, ischemia, scleroderma

\section{Context}

Annexin $\mathrm{V}$ is a calcium dependent phospholipid binding protein which is abundant in endothelial cells. Previous studies have shown that high titres of antibodies specific for annexin $\mathrm{V}$ may be found in patients with preeclampsia, rheumatoid arthritis and systemic lupus erythematosus (SLE). Importantly, in patients with SLE, the presence of anti-annexin V antibodies appears to be associated with features of an antiphospholipid syndrome. This raises the possibility that annexin $\mathrm{V}$ is one of many antigens which might be recognised by anti-phospholipid antibodies. It has been suggested that binding of anti-annexin $\mathrm{V}$ to annexin $\mathrm{V}$ on endothelial cells induces apoptosis of endothelial cells with consequent loss of their antithrombotic function. To determine the prevalence of anti-annexin $\mathrm{V}$ antibodies in patients with scleroderma, and to ascertain whether the presence of high titres of these antibodies was associated with any clinical features, particularly digital ischaemia.

\section{Significant findings}

High titres of anti-annexin $\mathrm{V}$ antibodies (defined as greater than the mean plus 3 standard deviations of titres found in healthy control individuals) were found in 12 out of $66(18.2 \%)$ of patients with scleroderma. Nine of 12 patients with scleroderma with high titres of anti-annexin V antibodies suffered from digital ischeamia compared with 13 out of 54 patients without high titres of these antibodies. Two

of 12 patients with anti-annexin $\mathrm{V}$ antibodies had possible features of an antiphospholipid syndrome (recurrent fetal loss and arteriosclerosis obliterans) and 1 out of 12 patients had detectable IgG anticardiolipin antibodies.

\section{Comments}

This study provides further circumstantial evidence implicating anti-annexin V antibodies in the pathogenesis of thrombotic/ischaemic disease. It is puzzling that in the context of SLE the presence of anti-annexin $\mathrm{V}$ antibodies is associated with large vessel thrombosis whilst in the context of scleroderma 
the presence of anti-annexin $\mathrm{V}$ antibodies appears to be associated with ischaemia within the territory of smaller vessels. The different phenotypes associated with the presence of the antibodies in different diseases suggests that the development of thrombosis/ischaemia is likely to be multifactorial.

\section{Methods}

The prevalence of anti-annexin $\mathrm{V}$ antibodies was determined in 66 patients with scleroderma (seen at an outpatient dermatology clinic) and 20 healthy controls using an ELISA assay. The possibility of an association between the presence of antibodies specific for annexin $\mathrm{V}$ and the presence of digital ischaemia was investigated. In addition certain other clinical and laboratory characteristics of patients with scleroderma and high titre anti-annexin $\mathrm{V}$ antibodies were analysed (specifically the presence of antibodies specific for extractable nuclear antigen (ENA) and anticardiolipin, prolonged activated partial thromboplastin time and symptoms of vascular events).

\section{References}

1. Sugiura K, Muro Y: Anti-annexin V antibodies and digital ischemia in patients with scleroderma. J Rheumatol. 1999, 26: 2168-2172.

This PDF file was created after publication. 